\title{
A POLÍTICA DA IGREJA UNIVERSAL E SEUS REFLEXOS NOS CAMPOS RELIGIOSO E POLÍTICO BRASILEIROS*
}

\author{
Ari Pedro Oro
}

Este texto versa sobre a inserção da Igreja Universal do Reino de Deus (IURD) na política nacional e seus efeitos nos campos religioso e político. ${ }^{1}$ Meus argumentos são os seguintes: em primeiro lugar, o sucesso eleitoral alcançado por essa igreja, até o presente momento, relaciona-se fundamentalmente com o seu carisma institucional, associado ao uso extensivo e intensivo da mídia e de um discurso que traz para o campo político importantes elementos simbólicos do campo religioso; e, em segundo, o sucesso político da Universal repercute tanto no campo religioso - produzindo

* A primeira versão deste texto foi apresentada no XXVI Encontro Anual da Anpocs, realizado em Caxambu, MG, entre os dias 22 e 26 de outubro de 2002, no GT Religião e Sociedade, coordenado por Lísias Negrão, Maria das Dores Machado e Joanildo Burity.

Artigo recebido em outubro/2002

Aprovado em abril/2003 um efeito mimético em outras igrejas e religiões que procuram, como ela, também expressar o seu capital político e poder institucional - como no campo político, provocando um interesse de alianças por parte dos partidos políticos.

\section{A Igreja Universal do Reino de Deus e a política}

A IURD iniciou a sua efetiva prática política em 1986 com a eleição de um deputado federal para a Assembléia Nacional Constituinte. Em 1990, elegeu três deputados federais e seis deputados estaduais. Em 1994, duplicou o número de deputados para a Câmara Federal e aumentou para oito o número de deputados para as assembléias legislativas. Naquele ano, no Rio de Janeiro, também obteve a Secretaria do Trabalho e Ação Social e apresentou uma candidatura para o senado que 
alcançou 500 mil votos (Freston, 2000). Por ocasião das eleições de 1998, a Universal elegeu 26 deputados nas assembléias legislativas de dezoito Estados da federação (Fonseca, 1998, p. 20) e dezessete deputados federais (sendo catorze egressos da própria igreja de distintas unidades federativas $^{2}$ e três deputados apoiados pela igreja), cuja soma situa-se na casa de 1.400 .000 votos, "[...] feito comparado a partidos de médio porte como PTB e PDT" (Conrado, 2000, p. 26).

Nas eleições 2000, a IURD elegeu dezenas de vereadores em todos os Estados do país. Já nas eleições de 2002 elegeu dezesseis deputados federais vinculados à própria igreja, ${ }^{3}$ dois a mais do que na legislatura anterior, e dezenove deputados estaduais, representantes de dez Estados da federação. ${ }^{4}$ Nessas mesmas eleições, segundo informações colhidas pela Folha de São Paulo junto ao deputado Bispo Rodrigues - o principal coordenador político da IURD 5 - a Igreja ajudou a eleger outros quatro deputados federais não pertencentes a ela (Folha de São Paulo, 10/10/2001). Além disso, fato notável foi a eleição do primeiro senador da Igreja, o bispo Marcelo Crivella, pelo PL do Rio de Janeiro, com 3.235.570 votos, superando políticos tradicionais como Artur da Távora e Leonel Brizola, além do pastor Manoel Ferreira, da Assembléia de Deus.

Dos catorze deputados federais da IURD constantes na legislatura 1998-2002, dez foram reconduzidos à Câmara Federal nas eleições de 2002. Os quatro restantes não concorreram à reeleição. A questão que fica no ar é saber se houve uma desistência voluntária dos mesmos ou a não candidatura se deveu a uma decisão da Igreja. Relativamente às eleições proporcionais para os legislativos estaduais, a IURD enfrentou, nas mesmas eleições de 2002, um problema até certo ponto inesperado. Trata-se de parlamentares estaduais apoiados ou egressos da própria Igreja em eleições passadas, mas que mesmo não recebendo o apoio da Igreja das últimas eleições concorreram "espontaneamente" à reeleição. Isso ocorreu, por exemplo, no Rio de Janeiro, no Ceará e no Rio Grande do Sul. ${ }^{6}$ Em seu lugar, a Igreja apresentou e apoiou outros candidatos que foram, em sua maioria, eleitos, diferentemente da- queles que se lançaram por conta própria, como veremos mais à frente, e amargaram uma estrondosa derrota.

Tudo indica que a retirada do apoio àqueles parlamentares se deveu ao fato de que eles ou não se submeteram às diretrizes e orientações estabelecidas pelos articuladores políticos da Igreja ou não atuaram de acordo com a expectativa alimentada por eles.

Atualmente, a IURD faz parte da aliança que dá sustentação ao governo Lula. Seu senador e parte dos deputados na Câmara Federal pertencem ao PL, partido aliado ao PT desde a campanha eleitoral. No entanto, como parte dos deputados da IURD se encontram em outros partidos, mesmo de oposição ao governo federal, é difícil prever um apoio unilateral da Igreja posto que seus congressistas em cada votação terão de optar, embora nem sempre isso seja possível, entre as orientações partidárias e os interesses da Igreja, não necessariamente coincidentes. Aliás, a mesma situação ocorreu por ocasião do segundo mandato do governo FHC (1999-2002) quando a IURD, por razões simbólicas e instrumentais, opôs-se ao governo central. No entanto, naquele momento, conforme sublinha Fonseca, a passagem da Universal para a oposição não se refletiu obrigatoriamente nas votações de seus parlamentares, o que significa que não haveria um "voto iurdiano" no Congresso Nacional. Segundo suas próprias palavras: "o comportamento do voto no congresso não aponta para uma real bancada Universal. Em geral os deputados seguem seus partidos [...]" (Fonseca, 1998, p. 20). Esse fato, porém, em vez de denunciar uma incapacidade política da IURD ou uma dificuldade de entendimento entre os deputados iurdianos, parece, antes, revelar o modo "sofisticado" de fazer política dessa Igreja, que distribui seus deputados em diferentes partidos para alcançar melhor poder de barganha política, o que não impede que em determinadas situações os interesses da Igreja se sobreponham aos dos partidos.

Há que se assinalar que a crescente presença de representantes da IURD no Congresso Nacional contribuiu substancialmente para aumentar o tamanho da assim chamada "bancada evangélica". Na le- 
gislatura 1998-2002, seu número era de 53 deputados ligados a treze igrejas (Época, 2/10/2000). ${ }^{7}$ Tudo indica que essa bancada saiu mais fortalecida nas eleições de 2002. Segundo a Folha de São Pau$l o$, "a bancada evangélica de deputados federais eleitos tem pelo menos sessenta parlamentares, donos de 5,1 milhões de votos", sendo 23 deputados filiados às Assembléias de Deus, 22 vinculados ou apoiados pela Universal, oito batistas e os demais de outras denominações, o que significa um aumento de cerca de $25 \%$ em relação à bancada anterior (Folha de São Paulo, 10/10/2002). Também no Senado houve um aumento de senadores evangélicos. Eram dois (Iris Rezende e Marina Silva) e agora são quatro (Marina Silva, Bispo Crivella, Magno Malta e Paulo Otavio).

No entanto, a "bancada evangélica" não constitui um grupo político coeso. Segundo Fonseca, são raros os temas e as votações em que se pode perceber a existência de uma unidade evangélica. Ela aparece em assuntos ligados à moral como a discussão em torno do aborto ou da união civil dos homossexuais. Por isso mesmo, continua Fonseca, "uma análise do comportamento do congressista evangélico mostra que esta 'bancada' [evangélica] é um mito" (Fonseca, no prelo). De certo modo, a revista Ecclésia também sustenta essa idéia ao dizer que "os congressistas ligados ao povo evangélico [...] são submetidos mais às orientações partidárias e aos interesses pessoais do que às igrejas que os elegeram" (Ecclésia, 81, set. 2002).

Assim sendo, salvo em alguns casos, no geral parece ser difícil se poder falar em "voto evangélico", assim como já observamos ser necessário relativizar a noção de "voto iurdiano". Aliás, semelhante prudência vale para a atribuição da posição político-ideológica da "bancada evangélica". Tida, geralmente, como "de direita e conservadora”, em verdade, como frisou A. Corten, ela não é mais conservadora do que a média da população. $\mathrm{E}$, especificamente sobre o pentecostalismo, "[...] não é nem mais nem menos conservador do que a igreja católica" (Corten, 1997, p. 18). A título ilustrativo, um levantamento efetuado por Fonseca na metade de 2001 acerca do vínculo partidário dos deputados evangélicos no Congresso Na- cional mostrou que eles se distribuíam tanto em partidos tidos como de "direita" como de "esquerda”. Mais especificamente, " 25 congressistas evangélicos estavam em partidos da oposição e 32 em partidos pro-governo" (Fonseca, no prelo).

\section{A eficácia política do carisma institucional}

Como procede a Igreja Universal para alcançar uma tal façanha no campo político? Ela resulta de um modo próprio de fazer política que, desde 1997, adotou, no âmbito nacional, o modelo corporativo da "candidatura oficial", cujo número de candidatos para os distintos cargos eletivos depende do capital eleitoral de que dispõe. Dessa forma, realiza, antes das eleições, uma campanha para os jovens de 16 anos obterem seu título eleitoral e efetua uma espécie de "recenseamento" de seus membros/fiéis, no qual figuram seus dados eleitorais. Tais dados são apresentados aos bispos regionais que, por sua vez, os transmitem ao Bispo Rodrigues. Juntos deliberam quantos candidatos lançam em cada município ou Estado, dependendo do tipo de eleição, baseados no quociente eleitoral dos partidos e no número de eleitores recenseados pelas igrejas locais. Uma vez lançados os candidatos, usam os cultos, as concentrações em massa e a mídia própria (televisão, rádio, jornal) - de acordo com a legislação eleitoral - para fazer publicidade dos mesmos.

Nas eleições de 2002, a IURD apresentou algumas novidades em relação às eleições passadas. Como nas demais, ao final dos cultos mais concorridos, sobretudo os dominicais, não somente era mencionado o nome e o número dos candidatos da Igreja aos cargos eletivos, mas, algumas vezes, os próprios candidatos eram apresentados aos fiéis/eleitores ou, em caso de sua ausência, os bispos ou os pastores faziam subir no "palco/altar" alguns banners com fotos dos candidatos. Além desses procedimentos, em 2002, em Porto Alegre, um mês antes das eleições, uma grande faixa foi afixada no fundo da "catedral da fé" contendo os dizeres: "vamos orar pelos nossos representantes" (seguiam os seus nomes), após o que aparecia a 
passagem de Provérbios 29:2: "Quando se multiplicam os justos o povo se alegra; quando porém domina o perverso o povo geme". E ainda, em alguns domingos um banner de uma urna eletrônica foi levado ao altar. Com ele o bispo ou o pastor que presidia a reunião ensinava, de forma bastante didática, seus fiéis a votarem em seus candidatos. Ainda, em Porto Alegre, no domingo dia 15 de setembro de 2002, uma urna eletrônica da Justiça Eleitoral foi posta à disposição dos fiéis no hall de entrada da catedral para os que quisessem treinar a votar.

Toda essa dedicação pedagógica, que teve reincidências e diversas expressões em outras capitais e cidades do país, talvez eleve a Universal à condição ímpar da principal instituição brasileira da atualidade a se ocupar com tamanha aplicação à conscientização e ao direcionamento do voto de seus membros. Mas, a racionalidade política da Igreja vai além e já foi demonstrada em outras ocasiões. Dependendo da eleição, ela distribui seus candidatos segundo os bairros, as cidades ou as regiões para serem apoiados separadamente pelas diferentes igrejas locais. Porém, repito, na IURD a escolha dos candidatos é prerrogativa única e exclusiva dos dirigentes regionais e nacionais da Igreja, segundo seus próprios cálculos e interesses. Não há nenhuma consulta democrática aos membros das igrejas locais. Estes recebem, no momento oportuno, o(s) nome(s) que devem apoiar. Muitas vezes, trata-se de pessoas pouco conhecidas pelos "irmãos de fé". Isso, porém, não inviabiliza suas eleições. Foi o caso de Valdir Caetano, um ex-metalúrgico do ABC paulista que, por ocasião das eleições de 2000, apesar de haver chegado a Porto Alegre há apenas três anos e meio, e ter se tornado pastor há um ano e meio, foi eleito vereador com quase onze mil votos (Zero Hora, 3/10/2000, p. 35), e de Almerindo Filho, que por ocasião das mesmas eleições era pastor há cinco anos e que antes de se candidatar a vereador em Porto Alegre, embora residisse nesta cidade, atuava como pastor no município vizinho de Viamão, distante vinte quilômetros da capital gaúcha.

Em razão desse procedimento que vigora na Universal, algumas vezes seus candidatos eleitos, nos distintos níveis da política, são também pessoas desconhecidas do grande público e da imprensa especializada em política, constituindo-se, então, "na surpresa" das eleições. ${ }^{8}$

Mas não é "qualquer um" que pode ser candidato na Igreja Universal. Ele deve ter o "germe do habitus" religioso e político, para usar a expressão de Jean Séguy (1982), tal como é concebido pelos dirigentes da Igreja. A esse propósito, Conrado efetuou um levantamento no jornal Folha Universal acerca do que é considerado pela Igreja o perfil adequado do político: "pessoas despojadas de interesses pessoais"; "ter o desejo exclusivo de glorificar o bom nome do Nosso Senhor Jesus Cristo [...]"; possuir "caráter" e "compromisso com o povo de Deus"; preocupar-se com os "desamparados, pobres e necessitados", "sem vaidades interiores, sem egoísmos [...]" (Conrado, 2000, pp. 76-77).

$\mathrm{Na}$ prática, como observou P. Freston, os principais pré-requisitos dos candidatos da Universal são os de serem "pastores que atuam na mídia" (Freston, 2000, p. 299). Ou seja, não seriam recém-chegados na Igreja e nem totalmente desconhecidos dos fiéis. No entanto, tais requisitos não são suficientes para garantir suas eleições. A votação que recebem, na espantosa porcentagem que pode chegar a 95\% do total dos fiéis da IURD, como mostrou a pesquisa Novo Nascimento, realizada pelo ISER, em 1994, ${ }^{9}$ resulta, em última instância, sobretudo do fato de terem sido escolbidos, indicados e/ou apoiados pelos dirigentes da Igreja como "homens de Deus", em favor dos quais é usada a "máquina iurdiana".

Portanto, Paul Freston tem razão ao dizer que na Universal há uma relação de complementaridade entre carisma institucional e qualidades pessoais dos candidatos (Freston, 2000, p. 299)..$^{10}$ No entanto, acredito que o primeiro pólo - institucional - é preeminente sobre o segundo - individual -, e isso se deve à estrutura eclesial carismática, centralizada e não participativa (Carneiro, 1998 $)^{11}$ que prevalece nessa Igreja. Ela é reconhecida como tal pelo próprio Bispo Rodrigues, quando afirma: "Nossa força é que temos uma hierarquia, há uma hierarquia que é seguida à risca [...]" (Jornal do Brasil, 29/10/2001), o que im- 
plica dizer que o poder da instituição prevalece sobre o dos indivíduos, sejam eles simples fiéis ou pastores. Esse poder chega a tal ponto que, segundo Conrado, o pastor eleito não é dono do seu próprio mandato. Ao contrário, "o político eleito pela IURD tem o seu mandato nas mãos dela, seguindo sua orientação nas questões de interesse da igreja. A legitimidade da sua representação deriva de um 'ato de instituição' que a organização faculta" (Conrado, 2000, pp. 54-55).

Evidentemente, é impossível não perceber que por trás do carisma institucional há um reduzido mas poderoso grupo de indivíduos, liderado pelo Bispo Rodrigues, que exerce seu poder nos vários momentos da atividade política iurdiana. Cabe a eles, de um lado, escolher os candidatos "representantes da Igreja", segundo o tipo de eleição em questão, bem como distribui-los entre os partidos políticos, e, de outro, orientar os bispos e os pastores locais para solicitarem os votos dos fiéis.

Diga-se de passagem, semelhante poder do staff dirigente da Igreja é verificado quando se trata de enviar pastores para o exterior. ${ }^{12}$ Diferentemente de outras igrejas missionárias, em que o "chamado interior" constitui um importante elemento motivador para o desempenho da atividade missionária, na IURD esta não será a razão para alguém atuar no exterior e sim o fato de ter sido enviado pela cúpula dirigente da Igreja. Aliás, o mesmo procedimento vale para as freqüentes transferências de pastores dentro do Brasil.

É claro que o sucesso do exercício da autoridade carismática institucional iurdiana na política não se dá de forma opressiva em relação aos seus fiéis. Ela é legitimada mediante a mobilização de vários elementos práticos e simbólicos. Por um lado, a Igreja faz uso da sua bem montada rede midiática, impressa e eletrônica, bem como de sua rede assistencialista, cujo fortalecimento ocorreu em 1994 com a criação da Associação Beneficente Crista (Cristã) (ABC), entidade que concentra a ação social e mantém diversos projetos assistenciais da Igreja..$^{13}$ Mas, por outro lado, ela traz para o campo político e para a construção de sua representação política, elementos doutrinários e discursivos próprios do campo religioso, reproduzindo um proce- dimento comum aos evangélicos, qual seja, "religiogizar o político".

De fato, a IURD tende a acionar o princípio milenarista, cuja intensidade guarda, até certo ponto, relação com as notícias veiculadas na imprensa nacional acerca da corrupção no campo político. Ou seja, quanto mais a mídia divulga casos de escândalos, mais a Igreja apela e aciona o componente milenarista que se expressa, por exemplo, nesta frase do Bispo Rodrigues: faz-se necessário "uma grande reforma espiritual na vida do povo brasileiro" (Rodrigues, 1998, p. 27), da qual pode resultar uma nova moral pública e uma nova ética na política. Para tanto, continua o referido bispo, é "papel da Igreja do Senhor Jesus Cristo: anunciar a verdade, doa a quem doer e cobrar das nossas autoridades a prática dos princípios éticos e morais do nosso povo, de acordo com a própria Carta Constitucional do país" (Idem, p. 29). Por isso mesmo, conclama o povo de Deus a eleger "homens e mulheres tementes ao Senhor Jesus [...]" (subentende-se evangélicos). ${ }^{14}$

Portanto, para a IURD, e outras igrejas pentecostais ou reformadas, a corrupção é a antítese dos princípios cristãos de valorização da comunidade, do bem comum e da fraternidade, constituindo-se no inimigo do bem-estar dos cidadãos. A corrupção justifica e legitima o ingresso na política, uma vez que eles se consideram uma espécie de "reserva moral" da sociedade.

Reitero que o discurso pela ética na política é recorrente nas igrejas evangélicas em geral. No entanto, como referiu R. Mariano, a experiência tem mostrado que em sua prática política "vários parlamentares pentecostais, membros de igrejas e partidos conservadores, protagonizaram escândalos variados de malversação de recursos públicos e revelaram possuir uma voracidade fisiológica que em nada diferia da dos piores de seus pares não crentes" (Mariano, 2000, p. 61).

Porém, quanto à atuação dos parlamentares iurdianos F. Conrado sublinha que eles não se envolveram em escândalos dessa ordem. É o que também escreveu - e não há novidade nisso - o Bispo Rodrigues, em 1998: 
[...] em meio a tantas falcatruas e espertezas [que vigora na política do país] os homens e mulheres que levam o nome de Deus [subentende-se a bancada parlamentar da IURD] não se deixaram contaminar pela prática comum da corrupção. Os nossos candidatos mostraram, na prática, o que é verdadeiramente a ética na política (1998, pp. 7-8)

E a defesa da ética e o combate à corrupção continuarão sendo seus objetivos, segundo declarou o mencionado Bispo ao jornal Folha Universal, logo após a sua reeleição:

Meu compromisso é manter a ética, cumprindo meu mandato em favor dos pobres e da nação. Quero combater a corrupção, lutar pela proteção do meio ambiente, pela reforma tributária, pela melhor distribuição de renda, partilha da terra, diminuindo a injustiça social (Folha Universal, edição 550, 19/10/2002).

Porém, a construção de uma outra sociedade e de uma outra política subentende a vitória na guerra espiritual em que a Igreja está inserida. Ou seja, a IURD, mas não só ela, apela diretamente para o discurso das "forças invisíveis" que atuam na política (Corten e Mary, 2000). ${ }^{15}$ Mais especificamente, a simbólica da diabolização - que, segundo Barros, constitui "[...] o eixo a partir do qual o universo simbólico desta igreja é construído" (1995, p. 1) - é a chave pela qual a Universal conclama seus fiéis a participarem da política para vencer o satanás. "Não votem nos políticos que estão a serviço de satanás, que não querem que a obra de Deus prospere", disse o bispo da Universal que presidiu o culto de 22 de setembro passado em Porto Alegre. "Os espíritos que atuam na política, disse recentemente o Bispo Rodrigues, são os espíritos dominadores, os príncipes das trevas" (Jornal do Brasil, 29/10/2001). Em outra oportunidade o mesmo bispo afirmou: "O diabo está alojado dentro do Congresso Nacional, criando lei injustas e erradas" (Folha Universal, 302, 18/1/1998). "A maioria dos políticos estão a serviço do satanás", repetiam pastores e bispos nos domingos que precederam a eleição de 6 de outubro de 2002.
Se, portanto, o diabo atua na política - ocasionando a corrupção e os comportamentos ilícitos e antiéticos -, a Universal se diz capaz de libertá-la do poder desse mal. Para isso, aciona um recurso invisível mas poderoso, a força que purifica tudo, inclusive a política: a "força do Espírito Santo", o "poder do Senhor Jesus", "o pai das luzes que vence o poder das trevas", segundo o dizer dos ministros da IURD.

A conseqüência desse discurso é que para os fiéis iurdianos votar não constitui apenas um exercício de cidadania. Ele também é concebido como um ato que preenche um sentido quase-religioso. Trata-se de um gesto de exorcismo do demônio que se encontra na política e de sua libertação para que ela seja ocupada por "pessoas tementes ao Senhor Jesus", segundo a expressão de Bispo Rodrigues. Em outras palavras, o efeito de sentido produzido pelo discurso e pelo carisma da IURD por ocasião do período que precede as eleições é tal que seus fiéis acrescentam um significado a mais ao ato de votar além do dever cívico. O gesto de votar adquire o sentido de um rechaço do mal presente na política e sua substituição pelo bem, ou seja, por pessoas convertidas ao evangelho, por "verdadeiros cristãos", por "homens de Deus".

Esse significado simbólico do voto para os fiéis da IURD ficou bem caracterizado nas eleições de 6 de outubro de 2002. Com efeito, a partir do domingo dia 22 de setembro todos quantos compareceram aos templos da Universal receberam um pequeno envelope que continha um cajado de treze centímetros de comprimento, feito de papelão resistente, portando os dizeres "os 10 dias da libertação". Em verdade, tratava-se de uma "campanha" que iniciou no dia 27 de setembro e que (não por coincidência) terminou no dia 6 de outubro. Como todas as campanhas promovidas pela Igreja, esta também se baseava na Bíblia, mais precisamente em João 8:36, que dizia "Se, pois, o Filho vos libertar, verdadeiramente sereis livres", e em Êxodo 14, que narra a passagem de Moisés pelo Mar Vermelho.

Ao explicar essa campanha na "Catedral da Fé", em Porto Alegre, no dia 22 de setembro, o 
bispo Alfredo Paulo acrescentou: "no dia 6 de outubro nós vamos votar com o cajado". E explicou:

Assim como o Senhor disse a Moisés: levanta a tua vara, estende a mão sobre o mar, e o Mar Vermelho se abriu, assim também nós vamos apertar os números na urna eletrônica com o nosso cajado e vamos abrir o mar do Evangelho, elegendo os homens de Deus. Vamos eleger os homens de Deus que vão trabalhar para a obra de Deus.

Como se vê, a Universal mobiliza na esfera política crenças, valores, símbolos e cosmovisões do seu universo simbólico, e a partir deles produz uma ressemantização do voto, inscrevendo-o "numa lógica cosmológica, na perspectiva da guerra santa" (Semán, 2001, p. 96). ${ }^{16}$

\section{O efeito mimético produzido pela Igreja Universal}

O sucesso político da IURD parece estar produzindo um efeito mimético no campo religioso. Assim, por exemplo, uma parcela da Assembléia de Deus vê a IURD como uma igreja que precisa ser imitada. Foi o que declarou o pastor João Ferreira Filho, presidente daquela Igreja no Rio Grande do Sul, no dia seguinte às eleições municipais de 2000, quando viu o fracasso eleitoral de sua denominação, que lançou em Porto Alegre quatro candidatos a vereador não elegendo nenhum, diferentemente da IURD, que lançou dois candidatos, elegendo ambos. Disse ele: "eu admiro muito a Universal, temos que imitá-la”. Vai na mesma direção o depoimento do conhecido pastor da Assembléia de Deus, Silas Malafaia: "Queremos exaltar o bonito exemplo da Igreja Universal, que define muito bem seus representantes no legislativo. As outras denominações deveriam imitá-la [...]" (apud Machado, 2001, p. 7). E essa não é a posição de um ou de outro pastor da Assembléia de Deus, pois em convenção nacional essa Igreja decidiu que nas eleições de 2002 iria indicar a seus seguidores candidatos a deputados, senadores, governador e presidente (Zero Hora, 16/10/2001).
No entanto, a imitação da IURD por parte da Assembléia de Deus vai até certo ponto. Nas eleições de 2002, a orientação da Convenção Geral das Assembléias de Deus foi no sentido de não exercer nenhuma "pressão ou orientação direta aos fiéis". Antes disso, afirmou o pastor João Ferreira Filho, em declaração ao jornal Zero Hora, de Porto Alegre, "deixamos claro que cada crente é livre para optar por um candidato" (Zero Hora, 2/1/2002 (cad. Jornal da Eleição, p. 10).

Assim sendo, no Rio Grande do Sul, por exemplo, nas eleições de 2002, a Assembléia de Deus apoiou oficialmente dois candidatos a deputado estadual, ambos já deputados e assembleianos, Eliseu Santos e Edmar Vargas, este último sendo inclusive pastor, que foi reeleito, com 49.574 votos, enquanto Eliseu Santos, com 37.640 votos, figurou na primeira suplência. Para deputado federal a Assembléia apoiou oficialmente um único candidato, que não possuía trajetória política, o pastor Milton Cardias. Com 40.802 votos também ficou na primeira suplência do PTB, partido de todos os candidatos citados. No entanto, em razão de preenchimento de cargos no primeiro escalão do governo do Estado, ambos os candidatos que estavam na suplência ocuparam suas cadeiras parlamentares.

Os próprios líderes religiosos da Assembléia de Deus reconhecem, porém, que a dificuldade de eleger os candidatos "oficiais" se deve ao fato de que outros membros da Igreja também se lançam candidatos, dividindo, conseqüentemente, os votos dos irmãos. ${ }^{17}$

Como se pode notar, a política da Assembléia de Deus consiste na indicação e na declaração de alguns candidatos por parte da cúpula dirigente local, mas dá liberdade aos seus fiéis de votar em quem desejarem, e não desaconselha outros fiéis a apresentarem seus nomes a cargos eletivos.

Outra igreja pentecostal que, nos últimos anos, ao menos no Rio Grande do Sul, tem se lançado mais diretamente na política, é a Igreja do Evangelho Quadrangular. Desde as eleições de 2000, ela também procedeu, em parte porém, de maneira semelhante à Universal. Com efeito, naquelas eleições, bem como nas proporcionais de 
2002, a Quadrangular efetuou em todos os municípios onde está instalada um levantamento de sua potencialidade política, decidindo então lançar ou não candidaturas "oficiais" da própria Igreja, ou de apoiar outras candidaturas. Assim, por ocasião das eleições de 2000, a igreja de Porto Alegre lançou como candidato oficial para a Câmara de vereadores o pastor Nilo Sergio dos Santos. Concorreu pelo PTB e obteve 2.333 votos, não se elegendo. Nas eleições 2002, em prévias realizadas no interior da Igreja em junho de 2002, indicou o já deputado Manoel Maria, do PTB, membro da Igreja, como candidato oficial da Igreja, e para a Câmara Federal indicou o pastor Reinaldo Santos e Silva, também pelo PTB. Ambos foram eleitos, o primeiro com 38.361 votos e o segundo com 43.716 votos.

Dessa forma, a prática política da Quadrangular apresenta uma diferença tanto em relação à Assembléia de Deus como à Universal. Enquanto essas igrejas não realizam prévias internas, a Quadrangular assim procede, de maneira semelhante ao que ocorre nos partidos políticos. Ou seja, essa Igreja privilegia um procedimento democrático de escolha de candidatos "oficiais", cuja eficácia é superior à produzida na Assembléia de Deus.

Assim, nota-se que tanto a Assembléia de Deus como a Quadrangular "imitam" a Universal até certo ponto. Não compartilham com o verticalismo desta última e reconhecem a liberdade do fiel de escolher seu próprio candidato, evangélico ou não, mesmo que indicado pelas igrejas. O procedimento das duas tradicionais igrejas pentecostais aproxima-se das orientações da Associação Evangélica Brasileira que, em documento intitulado "Voto Ético", emitido por ocasião das eleições 2002, preconizou, entre outras coisas, em seu Decálogo Evangélico, que "Nenhum cristão deve se sentir obrigado a votar em um candidato pelo simples fato de ele se confessar cristão evangélico" (VI mandamento), e que "O pastor deve ser obedecido em tudo aquilo que ensina sobre a Palavra de Deus, de acordo com ela. No entanto, no âmbito político-partidário a opinião do pastor deve ser ouvida apenas como a palavra de um cidadão, e não como uma profecia divina" (X mandamento).

A Igreja Católica, por sua vez, também não parece insensível diante do avanço na política dos evangélicos em geral e da IURD em particular, embora, evidentemente, não se possa estabelecer uma relação direta entre os dois fatos mesmo porque, como se sabe, essa Igreja tem historicamente participado da vida política nacional, embora com intensidade variada segundo as conjunturas.

No entanto, nos últimos anos podemos perceber um redobrado esforço católico em relação à política. Em primeiro lugar, observa-se, em distintas instâncias políticas, como nas câmaras de vereadores, nos legislativos estaduais e mesmo no Congresso Nacional, uma articulação entre políticos católicos e membros da hierarquia institucional no sentido de garantir, como diz Dom Antônio Cheuiche, bispo Emérito de Porto Alegre, um "novo espaço onde os parlamentares se reúnam para rezar, para melhorar a sua vida espiritual e aprofundar a consciência e seus conhecimentos sobre o compromisso político do cristão" (jornal Nova Versão, 18-24/10/2001, p. 5). Tais articulações resultaram, em certas cidades e Estados, bem como na Câmara Federal, na formação da chamada "bancada católica".

A segunda forma pela qual a Igreja Católica se inseriu nos últimos anos mais diretamente na política é pela divulgação, nos períodos eleitorais, de cartilhas de orientação política para os eleitores. Se, de fato, há uma recorrência da CNBB na emissão dessas cartilhas - como fez em 2002 com o documento intitulado "Eleições 2002", lançado por ocasião da reunião de Itaici no início de abril daquele ano - o fato de, além disso, aparecerem cartilhas "regionais", mostra o (redobrado) interesse da Igreja Católica com as eleições. Foi o que ocorreu no Rio Grande do Sul, onde o arcebispo de Porto Alegre, Dom Dadeus Grings, lançou em março de 2002 a "sua" cartilha de orientação para o "voto consciente" dos cristãos. Nela ressalta que "a igreja não deve optar por um partido político ou por um candidato" e que o período eleitoral é "muito bom para aprofundarmos o sentido de patriotismo, do civismo, da cidadania, e de todos lutando pelo bem comum" (jornal Versão Semanal, 21 a 27 de março de 2002).

Por fim, a Igreja Católica participa da política mediante a presença de membros do clero que concorrem a cargos eletivos. Nesse sentido, o setor 
Vocações e Ministérios da CNBB constatou que por ocasião das eleições 2000 houve um aumento de candidaturas de religiosos a cargos públicos. Um estudo de Moreira de Oliveira realizado junto a 176 dioceses brasileiras, correspondendo a 65,67\% do total, apurou que nas mencionadas eleições a quantidade de presbíteros candidatos "superou a faixa de cem padres” (Moreira de Oliveira, 2002, p. 263), tendo cerca de 70\% deles concorrido a cargo de prefeito, seguido de vice-prefeito e de vereador. Os dados da pesquisa mostraram que $41 \%$ dos padres candidatos concorreram pelo PT, seguido do PMDB, com 12\%, e pelo PSDB, com 9\%. A pesquisa revelou ainda que $44,77 \%$ dos candidatos venceram as eleições (Idem, pp. 264-265).

Nas eleições de 2002, no Rio Grande do Sul, dois membros do clero católico candidataram-se à Assembléia Legislativa, ambos pelo PT. O já deputado e sacerdote Roque Grazziotin, que nas eleições de 1998 recebera 29.113 votos, obteve 23.409 votos, ficando na segunda suplência; e Sergio Goergen - membro da Ordem dos Frades Menores da Província do Rio Grande do Sul - eleito com 44.633 votos. . Durante o governo Olívio Dutra, do PT, Goergen trabalhou, durante dois anos, na Secretaria da Agricultura como coordenador da Reforma Agrária.

Observe-se que diferentemente das igrejas pentecostais, a Igreja Católica não realiza prévias nem assume a candidatura oficial de seus membros que concorrem a cargos eletivos. Trata-se da postulação pessoal do clérigo que, após autorização do bispo e/ou do provincial o dispensando das atividades religiosas, passa a se dedicar temporariamente à política. Geralmente, a autorização é um processo difícil, e nem sempre obtém êxito, pois depende da posição teológica e ideológica do bispo da diocese, ou do provincial da Ordem Religiosa.

Finalmente, as federações e os membros das religiões afro-brasileiras também tentam ingressar na esfera política, ostentando um discurso de "desforra" e de enfrentamento diante dos opositores evangélicos. No Rio Grande do Sul, entretanto, esse discurso não tem alcançado um resultado positivo. Nas eleições 2000, em Porto Alegre, quatro importantes pais-de-santo concorreram a ve- reador, mas tiveram uma votação tão reduzida que mesmo somando todos os seus votos não lograriam eleger um único vereador. Antes disso, nas eleições legislativas de 1998, outro renomado pai-de-santo apresentou-se como candidato, e esperava receber 30 mil votos, mas obteve 3.425 . Em razão desses e de outros fracassos, as federações e os terreiros não apresentaram candidatos nas últimas eleições.

Acredito que o insucesso político das religiões afro-brasileiras guarda alguma relação com sua estrutura organizacional, formada pela variedade de federações e pulverização de terreiros, onde todos são, ao mesmo tempo, autônomos e rivais entre si. Não existe, no âmbito dessas religiões, uma hierarquia religiosa única, nem um poder centralizador e aglutinador dos centros religiosos. Ora, esse éthos constituído de permanente disputa, rivalidade e desqualificação mútua torna, como reconhece Prandi, bastante remota a possibilidade de união entre terreiros e grupos, mesmo em se tratando de proveito para a religião (Prandi, 1991, p. 163).

No entanto, e apesar dessas considerações, nas eleições de 2002 em outros Estados da federação foi melhor o resultado político das religiões afro-brasileiras. Em relação a São Paulo, por exemplo, a Folha de São Paulo apresentou no dia 3 de outubro a matéria "Os atabaques vão à forra", mostrando que as "religiões afro-brasileiras se organizam para eleger parlamentares que façam frente à bancada dos evangélicos" (Folba de São Paulo, 3/10/2002). O candidato Sebastião Arcanjo, o Tiãozinho, vereador pelo PT de Campinas, foi eleito para deputado estadual com 57.174 votos.

A tabela 1 foi elaborada a partir da observação do comportamento eleitoral de igrejas e religiões no Rio Grande do Sul nas eleições de 2002. Ela sintetiza os modelos de participação política de cada um dos segmentos religiosos referidos aqui e mostra a maior ou menor eficácia eleitoral de cada uma delas, em função do modelo adotado. Como se pode observar, em termos de eleição de candidatos indicados e apoiados, a Igreja Quadrangular conseguiu atingir o melhor índice de eficácia seguido da Universal e da Assembléia de Deus. 
Tabela 1

\begin{tabular}{l|c|c|c}
\hline Religião & Prévias & Candidatura oficial & $\begin{array}{l}\text { Exerce algum tipo de pres } \\
\text { são para direcionar } \\
\text { O voto dos fiéis }\end{array}$ \\
\hline Quadrangular & Sim & Sim & Sim \\
Universal & Não & Sim & Sim \\
Assembléia de Deus & Não & Sim & Não \\
Católica & Não & Não & Não \\
Afro-brasileiras & Não & Não & \\
\hline
\end{tabular}

É evidente que o efeito mimético produzido pela inserção política da Universal sobre as demais igrejas e religiões não significa a existência de uma relação direta, do tipo "causa e efeito". Por essa razão, é possível interpretar esse fenômeno a partir da teoria girardiana.

Com efeito, para René Girard, a mímese expressa rivalidade e desejo mediatizado pelo outro. Nesse caso, a Universal, assumindo o papel de mediador, atua no sentido de se fazer presente na política, o que desperta o mesmo desejo - ingressar na política - em outras igrejas e religiões. Ou seja, segundo essa teoria, o desejo (entrar na política) aparece nas outras igrejas - evangélicas, católica e religiões afro-brasileiras - porque ganhou força primeiramente na Universal. Assim, estamos diante de grupos concorrentes, embora, continua Girard, os que têm o desejo despertado pelo outro tendem a dissimulá-lo, afirmando que "seu próprio desejo é anterior àquele de seu rival". Além disso, "tudo o que vem desse mediador é sistematicamente depreciado embora secretamente desejado", e, até mesmo, "secretamente venerado" (Girard, 1961, pp. 25-27).

\section{A Igreja Universal, os partidos políticos e os candidatos}

Se, no campo religioso, o avanço iurdiano na política tende a produzir um "efeito mimético", no campo político também não passa despercebido. Ou seja, como afirma Flavio Conrado, o campo político não está mais alheio à força política que detém hoje a Universal na vida pública brasileira (Conrado, 2000, p. 77), e os evangélicos em geral, acrescentaria eu. Assim, há quem diga que por trás do empenho do PT em selar aliança com o Partido Liberal nas eleições 2002 - cuja razão mais explícita teria sido atrair o setor empresarial para o PT em torno de José de Alencar, empresário bem-sucedido e senador crítico da política econômica do governo FHC - figuraria também, mesmo que com motivação reduzida, o interesse velado de ter a Universal (e seus votos cativos?) ao seu lado. Esta é, por exemplo, a leitura que faz A. Fonseca, para quem "o Partido dos Trabalhadores prefere referir essas negociações (com o PL) como sendo não com a IURD mas sim com o PL" (Fonseca, no prelo).

Seja como for, o PT e a Universal já estabeleceram alianças em outras eleições e, nos últimos anos, mantiveram boas relações na Câmara federal. No entanto, lembremos que no primeiro turno da campanha presidencial de 2002 a Universal apoiou o também evangélico, Anthony Garotinho, do PSB. Isso ocorreu mesmo nos Estados em que a Igreja lançou candidatos a deputados e a senador pelo PL, partido aliado ao PT. Neste caso, prevaleceu o vínculo evangélico do candidato a presidente, somado às alianças produzidas, por exemplo, no Rio de Janeiro, entre os candidatos da Universal e a candidata vitoriosa ao governo do Estado.

No segundo turno das eleições presidenciais, porém, a Universal e o PL declararam seu apoio a Lula. "Temos a obrigação de entrar de cabeça na campanha do Lula", disse o Bispo Rodrigues à Radio CBN. "Nossos deputados, agora que já estão eleitos, devem se empenhar em mobilizar as suas bases". Bispo Rodrigues falava como vicepresidente nacional do PL e como responsável político da Igreja Universal. Além disso, a opção 
por Lula foi decidida pela cúpula da Universal, e também do PL, na esperança de que ele realizasse um governo voltado para os pobres, uma vez que, nas palavras do bispo,

[...] todos estão cansados de ideologia. A população quer saber como serão resolvidos problemas do transporte, educação, saúde, como será reduzida a miséria. Por isso vamos adotar uma nova forma de fazer política. Trata-se do socialismo de resultados (Jornal do Brasil, 13/10/2002).

Também Anthony Garotinho declarou seu apoio a Lula já na largada do segundo turno. De acordo com a imprensa, tanto Rodrigues como Garotinho atuaram como mediadores junto a outras igrejas evangélicas para conseguir apoio a Lula nas eleições de 27 de outubro de 2002. Assim, em 15 de outubro daquele ano a Igreja Renascer em Cristo expressou seu apoio à candidatura Lula e, no dia 17, o candidato reuniu-se no Rio de Janeiro com cerca de 900 pessoas de diversas igrejas que manifestaram seu apoio. Entre as igrejas estavam a Metodista, a Batista, a Sara Nossa Terra, além da Universal e dos pastores da Assembléia de Deus que não seguiram a decisão das duas principais convenções da igreja de apoiar Serra.

De fato, o candidato José Serra mobilizou-se pessoalmente para obter o apoio das Assembléias de Deus, bem como da igreja Quadrangular. Em 10 de outubro de 2002 recebeu o apoio da Convenção Nacional das Assembléias de Deus (Conade) e, em 16 de outubro, o apoio da Convenção Geral das Assembléias de Deus no Brasil (CGADB) e da Igreja Quadrangular. ${ }^{18}$

Vale registrar que semelhante interesse pelo apoio evangélico ocorreu nas eleições majoritárias dos Estados. Assim, por exemplo, no Rio Grande do Sul o candidato a governador Tarso Genro lançou em 27 de setembro de 2002, em Cachoeirinha, na região metropolitana de Porto Alegre, o Comitê Religioso de Apoio à Frente Popular, com a presença de representações de 36 igrejas evangélicas. No dia 19 de outubro, ambos os candidatos ao governo do Estado, T. Genro, da Frente Popular, e G. Rigotto, da União pelo Rio Grande, compareceram em Porto Alegre na matriz da Igreja Assembléia de Deus, onde estava sendo come- morado os 78 anos dessa Igreja na capital gaúcha. Também em Brasília, segundo o jornal Correio Braziliense, de 14 de outubro de 2002, os dois candidatos que chegaram ao segundo turno no Distrito Federal disputaram os votos do eleitorado evangélico.

É evidente, porém, que o apoio declarado pelos líderes evangélicos, mesmo que, segundo dizem, tenham consultado as "bases", não se traduziu em votos cativos, seja para um, seja para outro candidato. Isto porque, como se sabe, no momento preciso da decisão de voto outras variáveis entram em pauta, sem falar na divergência existente, tanto na hierarquia como na base dessas igrejas, em relação à questão de participar ou não da política e de apoiar unânime e explicitamente determinado candidato.

Portanto, em primeiro lugar, se por ocasião do primeiro turno das eleições presidenciais os evangélicos se inclinaram majoritariamente para a candidatura de Garotinho, no segundo turno houve uma divisão de intenção de voto entre os candidatos Lula e Serra. ${ }^{19}$ Em segundo, nunca na história republicana brasileira recente ocorreu uma aproximação tão grande entre política e religião, um interesse tão explícito e uma disputa tão aberta pelos votos evangélicos. Isso quer dizer que os candidatos e os partidos se deram conta de que os evangélicos constituem hoje uma importante força política, podendo até decidir uma eleição. Esta era, aliás, a ponderação/advertência feita por J. Burity, em 1997: "os partidos e candidatos que não levam em consideração os grupos religiosos em seu discurso e estratégia correm sério risco de se complicarem ou inviabilizarem eleitoralmente" (1997, p. 46).

Assim, como já havia aludido anteriormente, a aliança entre o PT e a Universal não é uma novidade - já tinha se concretizado em muitos municípios e Estados por ocasião das eleições de 2000. Naquela oportunidade, o denominador comum entre o partido e a Igreja foi o discurso pela ética na política. Durante o segundo turno da campanha eleitoral de 2000, Bispo Rodrigues compareceu em Porto Alegre, no programa eleitoral do PT, enaltecendo a "ética em governar" desse partido, e finalizou seu discurso com a frase: "Vote em quem governa com ética. Vote no PT". Por seu tur- 
no, durante a campanha desse partido em todo o Brasil, nas mesmas eleições, foi constante, de um lado, a denúncia contra a falta de ética por parte de governantes e políticos que davam sustentação política ao governo federal e, de outro, a irretocável conduta moral do PT: "passamos por essa campanha [de 2000] sem sermos alvos de uma única denúncia de corrupção", afirmou Lula (Isto $E$, $8 / 11 / 2000$, p. 4). Ou seja, a afinidade discursiva entre a Universal e o PT fundamentou-se, então, na idéia de "purificação da política" ou de "ética pela política". Nas eleições de 2002, a esse discurso foi acrescido um outro, que aproximou o partido e a Universal, qual seja, o da atenção aos pobres e ao trabalho na área social.

Há, porém, que se considerar, como já analisei em outro artigo (Oro, 2001), as importantes diferenças ideológicas existentes entre o partido e essa igreja no que concerne à defesa da ética na política. Com efeito, para o PT, trata-se de um princípio de respeito e valorização da cidadania, devendo os políticos, gestores da coisa pública (e não de interesses pessoais ou corporativos), cumpri-la com responsabilidade, transparência, justiça social e participação popular. Ademais, via de regra os eleitores do PT realizam a cidadania num contexto de racionalidade diferente da que prevalece entre os eleitores da Universal. Para estes, o discurso pela moralização enquadra-se no âmbito da batalha espiritual, o que abre espaço ao apelo de "forças invisíveis" que atuariam na política. Em outras palavras, a política é "suja", "corrupta" e "desonesta" devido, de acordo com a Igreja, à presença do demônio.

No entanto, a idéia de moralização da política, presente nos dois discursos, precisa ser analisado como um componente do imaginário político dessas duas instituições, o que não garante, por si só, sua efetivação empírica. Por isso, é necessário que se verifique até que ponto a prática política está isenta de ações corruptas e da preeminência dos interesses pessoais e corporativos.

\section{Conclusão: religião, política e democracia}

O envolvimento da IURD, em particular, e dos evangélicos, em geral, na política nacional sus- cita, entre outras coisas, duas importantes questões teóricas. Uma diz respeito às fronteiras entre o religioso e o político, e outra versa sobre as conseqüências do ingresso evangélico no universo político para a democracia e a cultura política brasileiras.

Com efeito, malgrado a separação oficial entre igreja e Estado, a história das relações entre política e religião no Brasil sugere menos a existência de autonomia e oposição entre esses campos do que de continuidade, ponte, trânsito e passagem, o que resulta na dificuldade de se traçar fronteiras claras. E mesmo atualmente, sugere J. Burity, verifica-se no Brasil "um arrefecimento da distinção entre religião e política" (1997, p. 77), ou, de acordo com J. J. de Carvalho, uma luta "[...] para ampliar a dimensão religiosa do espaço público e não por laicizá-lo" (1999, p. 16). Essa situação por certo ocorre não sem relação com a própria cultura brasileira e do lugar que nela detém o religioso. De fato, nosso país, como vários autores já sublinharam, malgrado o avanço da modernidade, é muito marcado pelo imaginário religioso (Ribeiro, 2000), em que "o domínio do 'sobrenatural' aparece como fundamental" (Velho, 1991, p. 31), o que faz do Brasil um país que jamais deixou de ser "religioso" (Giumbelli, 2002, p. 54). Conseqüentemente, completa Regina Novaes, são hoje muito "delicadas as relações entre religião e política" (2002, p. 64).

Em contrapartida, pode-se perguntar se o ofuscamento ou o deslocamento ou, ainda, a flutuação das fronteiras entre religião e política, para os quais, em nosso país, tem muito contribuído o ingresso recente das igrejas evangélicas na política, não revelam, como sugere Renato Janine Ribeiro, desgaste, esvaziamento, descrença ou mesmo desencantamento em relação à política, observados em parcelas importantes de nossa sociedade e, eu diria, também em outros países da América Latina e da África. ${ }^{20}$ Não haveria, nesse caso, uma "energia nova" pulsando em áreas que não têm tradição política, como, por exemplo, a esfera da religião? (Ribeiro, 2002). André Corten também discute essa idéia, ao sugerir que existe uma forma de política fora do âmbito político tradicional, mas a "extrema timidez" do pesquisador prejudi- 
ca sua compreensão a esse respeito, posto que ele ainda superestima "o instituinte político" (Corten, 2001, p. 159).

Eventualmente, prossegue Ribeiro, essas novas energias "[...] passam para o campo político ou são absorvidas por ele" (2002, p. 104). O problema, nesse caso, é saber "por que essa energia, que passa para o campo político, torna-se estéril?" (Idem, ibidem). Semelhante observação é feita por Corten quando afirma que se o pentecostalismo pode, por um lado, ser considerado um inst $i$ tuinte da sociedade - por exemplo, pela produção de identidades coletivas -, por outro, não constitui uma fonte instituinte do político, ou seja, não imprime uma marca diferenciadora em sua prática política (Corten, 2001). Essa situação ocorreria, segundo Mariano, em relação aos parlamentares evangélicos na política brasileira -, em razão da aceitação, e conseqüente submissão por parte desses indivíduos, às regras democráticas vigentes, ao império da lei e às normas jurídicas que regulamentam o funcionamento das instituições, dos partidos políticos, do regimento interno da Câmara etc. Isso imporia, caso haja intenção, limitações a toda e qualquer pretensão de ordem religiosa, teológica ou mesmo teocrática na política (Mariano, 2000). Em outras palavras, os políticos religiosos estariam submetidos a uma espécie de camisa-de-força: para atuar na esfera política precisam se submeter às regras, mas uma vez lá dentro encontram pouco espaço para uma prática política diferenciada.

Caso essa hipótese seja confirmada de maneira mais definida, poder-se-ia afirmar que, até o presente momento, o efeito, sobretudo o da presença da IURD na política, é mais perceptível no âmbito religioso, na medida em que, direta ou indiretamente, a Universal instiga outras igrejas e outras religiões a também participarem da vida política.

Quanto à relação com a democracia, como sublinha Dodson, podem-se observar diferentes tendências: alguns autores têm enfatizado as conseqüências sociais da expansão pentecostal; outros, sublinhado os efeitos políticos do pentecostalismo, particularmente no estímulo aos valores e às práticas democráticas; outros, ainda, são céticos quanto à possibilidade de haver uma relação benéfica entre religião e política (Dodson, 1997, pp. 25-26). Seja como for, importa destacar alguns pontos. Em primeiro lugar, os evangélicos seguem e aceitam as regras da vida democrática e do jogo político estabelecido; ${ }^{21}$ em segundo, o fato de eles comparecem na esfera política comprova a possibilidade democrática de participação; em terceiro, como sublinha Alexandre B. Fonseca, os evangélicos, pelo seu discurso crítico contra determinados procedimentos políticos anti-éticos, pela denúncia da situação difícil em que se encontram largos setores da sociedade, efetivamente contribuem , mesmo que de forma indireta, para a consolidação democrática no Brasil, (Fonseca, no prelo); finalmente, em quarto lugar, os evangélicos constituem uma fonte de mobilização política de setores sociais desfavorecidos. Para muitas pessoas, diz Fonseca, participar de uma igreja como a IURD significa a primeira experiência de "conversar sobre política" e de valorizar o voto (Fonseca, 1997). Se assim ocorre, para certos segmentos sociais, a política não passa mais rigorosamente pelas instâncias tradicionais de sua expressão, tais como sindicatos, cooperativas e partidos políticos. Em conseqüência- e no aguardo de novos dados etnográficos e de mais informações empíricas entendo, assim como Regina Novaes, que hoje "ser evangélico" "[...] tornou-se uma nova variável neste jogo de relações entre campo político e campo religioso" (Novaes, 2002, p. 91) e que uma boa postura epistemológica seria a de nem subestimar a inserção evangélica na política (brasileira e latino-americana), reduzindo-a a uma simples manifestação de uma cultura religiosa corporativa, nem supervalorizá-la, vendo-a como potencializadora da democratização da cultura política brasileira.

\section{NOTAS}

1 Embora este texto pretenda ter uma abrangência heurística nacional, os exemplos ilustrativos resultam, sobretudo, do Rio Grande do Sul, onde realizei uma pesquisa de campo mais longa e sistemática sobre o tema em questão. 
2 Quatro do Rio de Janeiro, três de São Paulo, dois de Minas Gerais, e um de cada um dos seguintes Estados: Bahia, Espírito Santo, Maranhão, Ceará, Rio Grande do Sul, Pernambuco e Paraná e Distrito Federal (Machado, 2001)

3 A saber: Almeida de Jesus (Ceará), Oliveira Filho (Paraná), Jorge Pinheiro (Brasília), João Paulo (Minas Gerais), Paulo Gouvea (Rio Grande do Sul), Reginaldo Germano (Bahia), Heleno (Sergipe), Bispo Wanderval (São Paulo), Bispo João Batista (São Paulo), Edna Macedo (São Paulo), Marcos Abrahão (São Paulo), Bispo Rodrigues (Rio de Janeiro), Bispo Vieira Reis (Rio de Janeiro), Bispo João Mendes (Rio de Janeiro), Divino (Rio de Janeiro) e Marcos de Jesus (Pernambuco).

4 São eles: Ronaldo (Ceará), Edson Praczyk (Paraná), George (Minas Gerais), Sergio Peres (Rio Grande do Sul), Marcio Marinho (Bahia), Madoqueu (Sergipe), Souza (São Paulo), Maria de Jesus (São Paulo), Roberto (São Paulo), Milton Vieira (São Paulo), Wagner Salustiano (São Paulo), Bispo Caetano (Rio de Janeiro), Bispo Jodenir (Rio de Janeiro), Bispo Leo Vivas (Rio de Janeiro), Armando José (Rio de Janeiro), Ely Patrício (Rio de Janeiro), Edna Rodrigues (Rio de Janeiro), Dilma Lins (Pernambuco) e Odete de Jesus (Santa Catarina).

5 Bispo Rodrigues foi eleito em 1998 deputado federal pelo Rio de Janeiro pela legenda do PFL com 76 mil votos. Foi reeleito no pleito de 2002 com 192.640 mil votos - quarta maior votação no conjunto dos candidatos à Câmara Federal do Rio de Janeiro. Ele é hoje vice-líder do Partido Liberal (PL) na Câmara Federal. Fundou a Igreja Universal na Argentina e na Espanha e trabalhou em Portugal, Angola, África do Sul e Moçambique antes de se dedicar integralmente, em 1996, à tarefa de coordenador político da Igreja. Conrado atribui o sucesso eleitoral da IURD, entre outros fatores, à liderança desse bispo que, desde a campanha presidencial de 1989, coordena candidaturas e define estratégias políticas da Igreja, além de conduzir na Câmara Federal a ação política dos parlamentares nas questões que interessam à sua instituição religiosa.

6 O jornal Folha Universal (15-21 set. 2002) divulgou uma nota esclarecendo que os deputados e os candidatos à reeleição para a Assembléia Legislativa do Rio de Janeiro, Mário Luiz e Magaly Machado, bem como o ex-pastor Eriberto da Silva Faria, também candidato a deputado estadual no Ceará, "não contam com o apoio dos membros da Igreja Universal do Reino de Deus". O mesmo ocorreu no Rio Grande do Sul, com o pastor Paulo Moreira.

7 Para uma análise da formação da bancada evangélica por ocasião da Constituinte de 1988, ver Pierucci e Prandi (1996). Para uma análise mais geral da bancada evangélica na Câmara Federal, ver Freston (1996 e 2000).

8 Por exemplo, o jornal Zero Hora referiu-se à eleição do pastor da Universal Valdir Caetano como a "surpresa do pleito no último domingo" (3/10/2000, p. 35).

9 Essa pesquisa constatou que "os fiéis da Universal concentram seus votos (95\%) em candidatos da própria igreja Universal" (Fernandes et al., 1998, pp. 146-147).

10 Como se sabe, para Weber carisma é uma qualidade extraordinária, de caráter extra-cotidiano - reconhecida como tal por um grupo social -, que caracteriza certos indivíduos (profetas, feiticeiros, chefes militares, "demagogos"), mas também instituições. A Igreja, por exemplo, possui um carisma de função, ou de instituição, derivado da apropriação de um carisma pessoal fundador (profético), rotinizado (Weber, 1971, p. 249). Segundo J. Séguy, “[...] para Weber, o carisma de função representa uma derivação institucional do carisma pessoal quando este se rotiniza e assume, no processo, significações e funções novas. O carisma pessoal, por sua vez, caracteriza o profeta (no domínio religioso), ou o 'demagogo' (no domínio político), ou ainda o chefe de guerra de qualidades excepcionais (no campo militar)" (1988, pp. 14-15). A relação entre carisma pessoal e graça institucional, diz Bourdieu, é de luta pelo monopólio do exercício legítimo do poder religioso. Ou seja, a igreja, "é incondicionalmente hostil ao carisma 'pessoal', isto é, profético, místico ou extático, que pretende indicar um caminho original em direção a Deus" (Bourdieu, 1987, p. 95). Ao mesmo tempo, a instituição religiosa preconiza que seus funcionários (padres ou pastores) "deve[m] se subordinar à graça institucional sob pena de condenação [...]" (Séguy, 1982, p. 33); eles devem reproduzir as obrigações articuladas pela instituição proprietária do carisma de função (Idem, p. 40).

11 Isto é, uma instituição em que "o carisma apresenta-se como o único elemento de organização do poder, da igreja local à organização nacional, constituindo um espaço institucional pouco propício à participação dos fiéis nos assuntos da Igreja" (Carneiro, 1998, p. 187). 
12 A Igreja Universal, como se sabe, está hoje presente em oitenta países, de todos os continentes, e a maioria dos pastores que atuam nesses lugares são brasileiros.

13 Como bem frisou A. Corten: "[...] as obras assistenciais permitem [às igrejas pentecostais] a constituição de uma base eleitoral (1997, p. 29).

14 Eis o pronunciamento completo do Bispo Rodrigues: "Conclamo o povo de Deus a que nos unamos em torno dos nossos ideais e não tenhamos medo de participar do processo político, elegendo homens e mulheres tementes ao Senhor Jesus a fim de que nossa sociedade seja transformada e possa ser orientada, segundo os verdadeiros princípios cristãos" (Folha Universal, 6/08/2000). O sociólogo e teólogo metodista Leonildo Campos lembra que o sonho de uma nova condição social, de uma reconstrução sociopolítica, vigora no conjunto do protestantismo brasileiro e se expressa nesta quase palavra de ordem: "O Brasil será um país diferente quando à sua frente estiver um homem de Deus" (2000, p. 21) Para uma análise atual do milenarismo pentecostalista, ver A. Corten (1995).

15 Para esses autores, o pentecostalismo dá continuidade a um processo de diabolização realizado pelos missionários, contribuindo, assim, para a globalização de um imaginário de forças do mal (Corten e Mary, 2000, p. 19).

16 Por outro lado, fica implícito que votar, para os fiéis da Universal, consiste na expressão de sua relação identitária com a Igreja mais do que com qualquer político ou partido. Ou, então, em certa medida a própria Igreja torna-se seu partido. Esse fato condiz com a concepção prevalecente na cultura brasileira, em que, segundo M. Palmeira, "o voto não é associado ao exercício de um direito individual, mas a uma sinalização de adesão a um 'lado' (facção) da sociedade" (Palmeira, 2000, p. 11), nesse caso, um vínculo identitário religioso e político.

17 Exemplo típico disso ocorreu em Porto Alegre por ocasião das eleições para vereador de 2000, quando a Assembléia de Deus apoiou oficialmente dois candidatos, mas não impediu que outros dois também se apresentassem como candidatos independentes. O resultado foi que nenhum deles se elegeu, perdendo, assim, uma cadeira, cujo representante ocupava há duas legislaturas.

18 Segundo a Folha Online (de 18/10/2002), em troca do apoio José Serra (PSDB) comprometeu-se a não patrocinar nenhum projeto ou lei que viesse a ferir os princípios e os interesses dos evangélicos, tais como: a união civil de homossexuais, a tributação da renda das igrejas evangélicas e a lei do silêncio.

19 Por isso mesmo, o jornal Zero Hora, de Porto Alegre, no dia do segundo turno das eleições, ironizou dizendo que a disputa não seria entre Lula e Serra, mas entre a Universal do Reino de Deus e a Assembléia de Deus (27/10/2002, Jornal da Eleição, p. 10).

20 Para uma visão atual e abrangente do pentecostalismo na América Latina e na África, ver Corten e Mary, 2000.

21 Nesse sentido, escreveu Bispo Rodrigues: "O povo brasileiro deseja que a verdadeira política exerça a isonomia, trazendo à existência a democracia esquecida desde os tempos da Antiga Grécia" (Rodrigues, 1998, p. 8).

\section{BIBLIOGRAFIA}

BARROS, Mônica do Nascimento. (1995), A batalha de Armagedom. Dissertação de mestrado, UFMG, Belo Horizonte.

BOURDIEU, Pierre. (1987), A economia das trocas simbólicas. 2 ed. São Paulo, Perspectiva.

BURITY, Joanildo. (2000), Religião e política na fronteira: desinstitucionalização e deslocamento numa relação bistoricamente polêmica. Trabalho apresentado no VIII Congresso Latino-americano de Religião e Etnicidade, promovido pela Associação Latino-americana para o Estudo das Religiões, Pádua, Itália, 27 jun.-5 jul.

(1997), Identidade e politica no campo religioso. Recife, IPESPE, Editora Universitária/UFPE.

CAMPOS, Leonildo Silveira. (2000), "Composições e recomposições do poder espiritual e político". Tempo e Presença, 22 (313): 20-23, set.-out.

CARNEIRO, Leandro Piquet. (1998), "Cultura cívica e participação política entre evangélicos", in Fernandes et al., Novo nascimento: os evangélicos em casa, na igreja 
e na política, Rio de Janeiro, Mauad, pp. 81-110.

CARVALHO, José Jorge de. (1999), "Um espaço público encantado: pluralidade religiosa e modernidade no Brasil". Série Antropologia, UnB, 249.

CONRADO, Flávio César dos Santos. (2000), Cidadãos do Reino de Deus: um estudo da Folha Universal nas eleições de 1998. Dissertação de mestrado defendida junto ao Programa de Pós-graduação em Sociologia e Antropologia da Universidade Federal do Rio de Janeiro.

CORTEN, André. (1997), "Pentecôtisme et politique en Amérique Latine". Problèmes d'Amérique Latine, 24: 11-32, jan.-mar.

(1995), Le pentecôtisme au Brésil: émotion du pauvre et romantisme théologique. Paris, Karthala (título em português, Os pobres e o Espírito Santo, Petrópolis, Vozes, 1996).

. (2001), "O pentecostalismo transnacionalizado no contexto teológico-político". Horizontes Antropológicos, Porto Alegre, PPGAS, pp. 149-160.

CORTEN, André \& MARY, Andre. (2000), "Introduction", in Imaginaires politiques et pentecôtismes, Afrique/Amérique Latine, Paris, Karthala, pp. 11-33.

CORREIO BRAZILIENSE, Brasília, edição de 14/10/2002.

CORREIO DO POVO, Porto Alegre, edição de 21/05/2001.

DODSON, Michael. (1997), "Pentecostals, polítics, and public space in Latin America", in Edward L. Cleary e Hannah W. stewartGambino (eds.), Power, politics and pentecostals in Latin America, Boulder, Westview Press, pp. 25-40.

ECCLÉSIA, São Paulo, 81, set. 2002.

ÉPOCA, 142, 2 out. 2000.

FERNANDES, R. C. et al. (1998), Novo nascimento: os evangélicos em casa, na igreja e na política. Rio de Janeiro, Mauad.
FOLHA DE SÃO PAULO, edições de 28/10/2000, 3/10/2002 e 10/10/2002.

FOLHA UNIVERSAL, edições de 10/1/1998, 16/11/1999, 6/8/2000, 13/10/2002 e $19 / 10 / 2002$.

FONSECA, Alexandre Brasil. (1998), "A maior bancada evangélica". Tempo e Presença, 302: 20-23, nov.-dez., São Paulo, Cedi.

(1997), Evangélicos e mídia no Brasil. Dissertação de mestrado, IFCS, Universidade Federal do Rio de Janeiro.

. (no prelo), Religion and democracy in Brazil (1998-2001): a study of the leading evangelical politicals.

FRESTON, Paul. (2000), "The political evolution of Brazilian Pentecostalism, 1986-2000”, in André Corten e Andre Mary (orgs.), Imaginaires politiques et pentecôtisme: Afrique et Amérique, Paris, Karthala, pp. 287-306.

(1996), "The protestant eruption into modern Brazilian Politics". Journal of Contemporary Religion, 11 (2): 147-168.

GIRARD, René. (1961), Mensonge romantique et vérité romanesque. Paris, Bernard Grasset.

GIUMBELLI, Emerson. (2002), O fim da religião: dilemas da liberdade religiosa no Brasil e na França. São Paulo, Attar Editorial, $\mathrm{CNPq} /$ Pronex.

HERVIEU-LÉGER, Danièle. (1997), "Croire em modernité: au-delà de la problématique des champs religieux et politique", in Patrick Michel (ed.), Religion et démocratie, Paris, Albin Michel, pp. 361-381.

ISTO É, edição de 8/11/2000.

JORNAL DO BRASIL, Rio de Janeiro, edição de 29/10/2001.

MACHADO, Maria das Dores Campos. (2001, inédito), Religião e política: evangélicos na disputa eleitoral do Rio de Janeiro. 
MARIANO, Ricardo. (2000), "Islâmicos e evangélicos na arena política”. Veredas, I: 49-64, ago., Belo Horizonte.

. (1999), Neopentecostais: sociologia do novo pentecostalismo no Brasil. São Paulo, Loyola.

MOREIRA DE OLIVERIA, Jose Lisboa. (2002), “A candidatura de presbíteros a cargos políticos". Eclesiástica Brasileira, 246: 259296, abr.

NOVAES, Regina. (2002), "Crenças religiosas e convicções políticas: fronteiras e passagens", in Luis Carlos Fridman (org.), POlítica e cultura, século XXI, Rio de Janeiro, ALERJ/Relume Dumará, pp. 63-98.

. (1999), "Pentecôtisme à la brésilienne: des controverses en cours". Archives des Sciences Sociales des Religions, 105: 125143, jan.-mar.

NOVA VERSÃO, Porto Alegre, edições de 1824/10/2001 e 21-27/3/2002.

ORO, Ari Pedro. (2001), "Religião e política nas eleições 2000 em Porto Alegre (RS)". Debates do NER, 3: 9-70, set., PPGAS/UFRGS, Porto Alegre.

. (2000), "Pentecôtisme et politique au sud du Brésil”, in André Corten e Andre Mary (orgs.), Imaginaires politiques et pentecôtismes, Afrique/Amérique Latine, Paris, Karthala, pp. 307-320.

PALMEIRA, Moacir. (2000), "Eleição municipal, política e cidadania”. Tempo e Presença, 311: 7-15, maio-jun.

PIERUCCI, Antonio Flavio \& PRANDI, Reginaldo. (1996), A realidade social das religiões no Brasil. São Paulo, Hucitec.

PRANDI, Reginaldo. (1991), Os Candomblés de São Paulo. São Paulo, Hucitec/Edusp.

RIBEIRO, Renato Janine. (2002), "Religião e política no Brasil contemporâneo", in Luis Carlos Fridman (org.), Política e cultu- ra, século XXI, Rio de Janeiro, ALERJ/ Relume Dumará, pp. 99-110.

COUTO, José Geraldo. (2000), "Entrevista com Renato Janine Ribeiro", in Quatro autores em busca do Brasil, Rio de Janeiro, Rocco, pp. 57-87.

RODRIGUES, Bispo Carlos. (1998), A igreja e a política. Rio de Janeiro, Ed. Universal.

SANCHIS, Pierre. (1998), "Comentário sobre a pesquisa”, in Fernandes et al., Novo nascimento: os evangélicos em casa, na igreja e na política, Rio de Janeiro, Mauad, pp. 150-168.

SÉGUY, Jean. (1988), "Charisme de fonction et charisme personnel: le cas de Jean-Paul II", in SEGUY et al. Voyage de JeanPaul II en France, Paris, Cerf, pp. 11-34.

(1982), "Le clergé dans une perspective sociologique ou que faisons-nous de nos classiques?". Trabalho apresentado no VI Colloque du C. S. P., Prêtres, pasteurs et rabbins dans la société contemporaine, Paris, Cerf, pp. 11-58.

SEMÁN, Pablo. (2001), "A Igreja Universal do Reino de Deus: um ator e suas costuras da sociedade brasileira contemporânea". Debates do NER, 3: 87-96, set., PPGAS/UFRGS, Porto Alegre.

$V E J A$, edição de 3/11/1999.

VERSÃO SEMANAL, edição de 21-27 de março de 2002.

VELHO, Gilberto. (1991), "Indivíduo e religião na cultura brasileira: sistemas cognitivos e sistemas de crença”. Novos Estudos CEBRAP, 31: 121-129, out., São Paulo.

WEBER, Max. (1971), Economie et société. Paris, Plon.

ZERO HORA, RBS, Porto Alegre, edições de $3 / 10 / 2000, \quad 12 / 11 / 2000, \quad 16 / 10 / 2001$, 2/1/2002, 15-21/9/2002 e 27/10/2002. 


\section{A POLÍTICA DA IGREJA UNI- VERSAL E SEUS REFLEXOS NOS CAMPOS RELIGIOSO E POLÍTICO BRASILEIROS}

\author{
Ari Pedro Oro
}

\section{Palavras-chave}

Igreja Universal do Reino de Deus; Campo político brasileiro; Campo religioso brasileiro; Evangélicos na política; Pentecostalismo.

Este texto versa sobre a inserção da Igreja Universal do Reino de Deus (IURD) na política nacional e seus efeitos nos campos religioso e político. Em razão da eficácia de seu carisma institucional, a Universal procedeu, dentro do próprio grupo religioso, a uma ressemantização do ato de votar em particular e da percepção da política em geral, inscrevendo-os em sua lógica religiosa. Isso é uma importante chave explicativa para o elevado grau de fidelidade de votos e o êxito político cada vez maior constatado nas últimas eleições. Ademais, a prática política da Universal está produzindo um efeito mimético em outras igrejas evangélicas, que tendem a imitar seu modelo de fazer política. Sua inserção política, sobretudo por intermédio do Partido Liberal, não passa despercebida pelos partidos, constituindo-se, assim, em um ator relevante na atual conjuntura política brasileira.

\section{THE POLITICS OF THE UNI- VERSAL CHURCH AND ITS CONSEQUENCES IN THE BRAZILIAN RELIGIOUS AND POLITICAL FIELDS}

Ari Pedro Oro

\section{Key words}

Universal Church of the Kingdom of God; Brazilian political field; Brazilian religious field; Evangelicals in Politics; Pentecostalism

The paper analyses the insertion of the Universal Church of the Kingdom of God (UCKG) in the national politics scenario and its effects in the religious and political fields. Due to the efficacy of its institutional charisma, the Universal Church of the Kingdom of God (UCKG) has given, within its own religious group, a new meaning to the specific act of voting and to the general perception of politics in general, putting both of them in its own religious logic. This is an important explanatory key for the high level of loyalty in voting and the growing political success verified in every new election. Furthermore, the political practice of the UCKG is producing a mimetic effect on other evangelic churches, which tend to imitate its way of doing politics. Its political insertion, mainly through the Liberal Party, has not remained unnoticed by the political parties, making the fact a relevant actor in the current Brazilian political conjuncture.

\section{LA POLITIQUE DE L'ÉGLISE UNIVERSELLE ET SON IMPACT DANS LES DOMAINES RELIGIEUX ET POLITIQUE BRÉSILIENS}

Ari Pedro Oro

\begin{abstract}
Mots-clés
Eglise Universelle du Royaume de Dieu; Domaine politique brésilien; Domaine religieux brésilien; Evangéliques dans la politique; Pentecôtisme.
\end{abstract}

Ce texte se rapporte à l'insertion de l'Église Universelle du Royaume de Dieu (EURD) dans la politique nationale et de ses effets dans les domaines religieux et politique. Du fait de l'efficacité de son charisme institutionnel, l'Église Universelle du Royaume de Dieu a procédé, à l'intérieur de son propre groupe religieux à une nouvelle interprétation de l'acte de voter et, de façon plus globale, de la propre perception de la politique, en les inscrivant dans sa logique religieuse. Cela peut expliquer le taux élevé de fidélité électorale et le succès politique croissant que l'on a pu constater lors des dernières élections. En outre, la pratique politique de l'Universelle est en train de produire un effet mimétique à l'extérieur de l'Église, surtout dans d'autres églises évangéliques qui imitent sa façon de faire de la politique. Parallèlement, l'insertion politique de 1'EURD, en particulier par le Parti Libéral, ne passe pas inaperçue aux autres partis politiques et transforment cette église en un nouvel acteur politique de la scène politique brésilienne. 